\title{
Review of Ethiopia Education Sector Development Programme VI in Perspectives of Filling the Labour Market Skill Gap
}

\author{
Dr. Chala Wata Dereso ${ }^{1}$ Dr. Shashi Kant ${ }^{2}$ \\ 1. College of Education and Behavioral Science, Department of Educational Planning \& Management, Bule \\ Hora University, Ethiopia \\ 2. College of Business and Economics, Department of Management, Bule Hora University, Ethiopia
}

\begin{abstract}
Skill gap in Labour market at both domestic and international level is the current agenda of higher education systems of Ethiopia to across the globe opportunities as a domestic unemployment challenges because of divide gap between what is delivered and what is expected. It is concern because the direct result of this mismatch is increasing unemployment and widening social divide. Therefore government focus at Education Sector Development Programmes and policies to generate transformational plans to change the substructure. Education is the root of transformation of all sectors of economy. So review of education sector development programmes VI in perspectives of filling the labour market skill gap is evitable in nature.
\end{abstract}

Keywords: Higher Education, Labour Market, Policy and Strategy, Skill Gap.

DOI: $10.7176 / \mathrm{JCSD} / 67-01$

Publication date: January $31^{\text {st }} 2022$

\subsection{Introduction}

Labour market faces drastic changes in its both structure and demand because of rise of technology and advancement of economy (Achchab \& Temsamani, 2022). Simultaneously labour market faces inequalities because of difference in hierarchical social structure and unequal opportunities for resource access (Barbieri \& Gioachin, 2022). In the era of digital labour market the demand of skill labour rises very fast because quality of skilled labour decided the direction of economic growth of a economy. This creates a gap between demand side of labour market and supply side of skilled labour (Bannò et.al, 2022). Foremost reason for this demand and supply side gap among of labour market is tertiary unskilled graduates produced by the universities especially in Ethiopia (Mekonnen, 2021). In Ethiopia, there is an significant gap still exists between skills, knowledge and attitudes are relevant to preparing the graduates for careers as professional labour and due care were the most important for make them skilled. So there is a urgent need of provide better skills and training to graduate students in bridging the perceived skills gap (Getahun \& Mersha, 2020). Skill gap leads to labour market inefficiencies and failures (Mustapha \& Osho, 2019).

\subsection{Rational of Study}

Ethiopia is a country of young population with over 70 percent of the total population is below the age of 30 that is the base of labour market (Anteneh et. al., 2022). But in spite of this huge young population a visible gap exist between demand side of labour market and supply side of skilled labour (Bannò et.al., 2022).Education imparted by universities are lop sided and traditional in nature, so skilled based learning is the solution the fill the divide between labour market skill demand the graduates supply by the universities in Africa. By skilled based learning universities will mainstream the resultants of this divide like poverty (Susilaningsih et. al., 2022). In Ethiopia, student's perception about employment oriented education is not healthy. They considered it as inferior to normal education (Wudneh et. al., 2022). Thus for access, equity, and internal efficiency in general education Ethiopia federal ministry of education developed education Sector Development Programme VI in perspectives of filling the Skill Gap in Labour market for a period of 2013 - 2017 E.C. $(2020 / 21$ - 2024/25 G.C.) Ministry of Education of the Federal Democratic Republic of Ethiopia has been conducting Education Sector Development Plan (ESDP) for the last twenty five years. By implementing all of the previous ESDP-1 to ESDP-5, huge achievements have been registered in Access to Education and Coverage, though a longer mile is still remaining in terms of Education Quality, Equity, especially for students with Special Needs and those from pastoralist community (Assefa, 2022).The current Education Sector Development Plan, ESDP-6, is designed to strongly address the gaps of the previous EDSPs. Additionally Hallmarks of ESDP-6 are the new and revised curricula after more than two and half decades, use of digital technology for quality improvement, new thoughts in to the non-Formal and Adult Education, , introduction of skills training at Grade-11 and Grade-12 so that hundreds of thousands of students completing secondary education system become junior professionals in their areas of Training. This, in particular, is aimed to enabling the General Education produce skilled labor for the job market without requiring college level education for those that might not have the chance to join Tertiary Education (Feyisa et. al., 2022).

Formal approaches to education and life skills for communities grounded in human capital and human 
rights approaches have failed to achieve the social change objectives of resilience and sustainable development. Life skills informed by indigenous pastoralist perspectives regarding what skills matter most, for what purposes, and how they are (or can be) taught to children and young people may offer a new perspective on how to conceptualize and teach these skills through the education system (Yitbarek,2022).

\subsection{Review of ESDP VI Plan}

Education Sector Development Programme (ESDP) is the sixth phase of education sector developmental plan started in year 2021 for the next five years i.e., for 2020/21 - 2024/25 G.C., with the objectivise to providing knowledge, skills and values, which prepares all students as citizens with competency, creativity, productivity and responsibility. This plan is released in the year 2021 is called Education Sector Development Programme VI (ESDP VI).

ESDP (VI) plan central towards nurturing the young with life skills that are needed by the global market by put forwarding the revolutionary changes in education sector through creating the vocational base of the secondary level education at first stage especially developing the labour market required skills generation at Grade-11 and Grade-12 with help of career awareness and job shadowing activities. ESDP VI included the seven major programmes but its third Programme that is "Quality improvement and relevance to the labour market", and fifth programme," Preparing students for the labour market through a career and technical education programme" especially designed for filling the divide between global market demands and skill gap

\subsection{Labour Market Imperfections and Skill Nurturing}

The execution of Education Sector Development Program (ESDP) III (2010/2011) remarked that one of the difficulties of the Ethiopian education sector that should be tended in the arrangement of ESDP IV (2010/20112014/2015) is improvement in student accomplishment through reliable spotlight on the upgrade of the teaching and learning process. Therefore, ESDP VI cantered towards quality education on base of skills development and values addition to promote citizenship behaviour among the students especially guidelines are clearly demonstrated for this in Education Sector Development Program, Programme 3 ( Lerra, 2021).

This programme is committed towards providing quality teaching and teachers by the end of 2025 and developing the student support system sidewise for higher secondary education (Dereso et. al., 2021).The ESDP VI framed on the periphery of educational approach of learning that uses Science, Technology, Engineering, the Arts and Mathematics as access points for nurturing the entrepreneurial spirit among learners to full fill the imperfections of labour market in Ethiopia (Kant et. al., 2021).

Career and technical education (C\&TE) is framed to nurture learners to become responsible citizens, personnel, and decision makers in a universal economy, while providing lifelong learning and academic and technical preparation for success in their chosen career (DeJaeghere et. al., 2022). Through formal and informal opportunities, every learner reaches his/her full potential to work in teams and take leadership roles, and to demonstrate entrepreneurship, resilience, emotional intelligence, and strong communication skills. Special consideration will be given to children challenged by natural or anthropogenic challenges so that they can receive the same services and continue their education in an environment conducive to learning and teaching In Ethiopia education plan ESDP VI preference of vocational education over is clearly manifested to create a skill development based ecosystem (Socwell, 2022).

\subsection{Intrinsic international inclusion}

Broadening the width and quality of instructive programs has been framed to make connect Ethiopian universities with international linkages and alliance as a continuation of ESDPV (Admasu \& Desta, 2021). To an extent the structure of education in Ethiopia is supported by international partners by providing financial assistance as well as personal support to the implementation of education programmes to support international labour market demands.

\subsection{Evaluation}

In ESDP $\mathrm{V}$ period, annually they contribute about $156 \$$ million that is near about 6 percentage of overall education budget. The ESDP VI focused on more inclusive approach by linkage of major partners and there active visibility. In the shadow of COVID-19 pandemic ESDP VI faced some challenges to maintain its motion. So it needs additional efforts and resources to mitigate with uncertainty.

The guidelines framed for linkage with labour market by fulfilling the demand and supply of skilled labour has not been sufficiently provided with policy guidelines to describe rationales, objectives and means and lay down guiding principles for individual institutions in their efforts towards internationalization.

Some of the Education policy documents provided very broad guiding principles on the necessity of establishing labour market connections with skilled personal development and supply. Time frame designed to complete the objectives is limited in nature. 
There was a lack of human capacity, both at the dedicated both at administrator level and at the regional level. Qualified teachers and classroom facilitators and the shortage of skilled teachers resulted in overcrowded classrooms, teachers on low-paid temporary contracts, inadequately trained teachers, and low overall teacher motivation. Inadequate $\mathrm{O}$-class facilities and lack of learning resources have also been a concern. Poor education quality, including inadequate infrastructure and WASH facilities, inadequate learning resources, overcrowded classrooms, poorly trained teachers, and teacher absenteeism often contributes to children leaving school. Some students have been pushed through to higher grades regardless of their skill attainment and end up leaving school because they are not able to follow their lessons.

No in-service training programmes have been established in the emerging regions, due to the absence of ownership of evening and distance education, the unavailability of in-service training guidelines, lack of awareness of in-service training programmes among the concerned bodies, the lack of strong and effective structural arrangements, the absence of policy and strategy, and the lack of commitment among educational leaders at all levels.

\subsection{Recommendations}

The quality of education and training at all levels is to be enhanced to improve learning outcomes. All students will have the opportunity to achieve high levels of learning outcomes, comparable to those of high performing international systems. There is a need to maintain and strengthen national learning assessments for improvements. Vocational skills assessments and exit examinations will be strengthened. Thus, the aspiration is to be among the best performing countries in the region in terms of student performance in international assessments such as TIMSS and PISA, as well as in world skill competitions, in 10 years' time. System-wide accreditations will continue to be maintained and strengthened at all levels to meet international, regional and national standards. The quality of general education will be improved by providing knowledge, skills and values that make all students creative, competent, productive and responsible citizens the unity of the country, appreciating shared values, diversity, interculturality, brotherhood, peace and inclusion. To align with current and future labour markets, curriculum flexibility will be introduced in Grades 11 and 12 to provide equitable access to the skills, knowledge and values needed to access different career paths and to make effective use of school resources. Likewise, STEAM-specific curricula will be updated and offered to enhance subject knowledge and develop skills and abilities.

Through a modular approach to teaching, higher education institutions (HEIs) will also develop new courses and programmes that respond to current or emerging labour market needs. ICT will be systematically and extensively integrated into all HEIs programmes. Courses will also be offered both online and through blended approaches. Also, quality practical training will be provided to existing science and technology and art teachers, as well as laboratory and workshop assistants, as part of the new STEAM approach.

The current CPD system will also be revised and an effective system will be established for science and technology teachers. Secondary school graduates, as part of the general education professionalized curriculum, will also complete a vocational and technical education programme in addition to core academic subjects in Grades 11 and 12 in seven areas: manufacturing, construction, biological and chemical sciences, information technology and computer science, business science, language and social sciences, performing arts, and visual arts, in order to acquire the knowledge, skills, attitudes, and entrepreneurial foundations necessary to enable them to join the world of work upon completion of general education.

\section{References:}

- Achchab, S., \& Temsamani, Y. K. (2022). Use of Artificial Intelligence in Human Resource Management:"Application of Machine Learning Algorithms to an Intelligent Recruitment System". In Advances in Deep Learning, Artificial Intelligence and Robotics (pp. 203-215). Springer, Cham.

- $\quad$ Admasu, E., \& Desta, A. (2021). Internationalization of Higher Education System in Ethiopia: A Review of Education Policies and Strategies. Agathos: An International Review of the Humanities \& Social Sciences, 12(1).

- $\quad$ Anteneh, Z. A., Engida, H. B., Mamuye, M. A., Yehun, Y. T., Guadie, A. G., Dagnew, Y. A., ... \& Gelaw, T. T. (2022). Patterns of cardiovascular diseases among cardiac disease suspected patients in Bahir Dar City, Ethiopia: Rheumatic heart disease in patients suspected with Heart diseases. Ethiopian Medical Journal, 60(01).

- Assefa, Y. (2022). Exploring "Intersectoral Collaboration" towards the Integration of Indigenous Knowledge into Adult Education Programs in North Wollo, Ethiopia. Education Research International, 2022.

- $\quad$ Bannò, M., Filippi, E., \& Trento, S. (2022). The Automation of Occupations in Europe: The Role of Labour Market Institutions and Human Capital. Available at SSRN 4003932.

- Barbieri, P., \& Gioachin, F. (2022). Social origin and secondary labour market entry: Ascriptive and 
institutional inequalities over the early career in Italy and Germany. Research in Social Stratification and Mobility, 77, 100670.

- DeJaeghere, J., \& Murphy-Graham, E. (2022). Life Skills Education for Youth: Critical Perspectives.

- Dereso, C. W., Kant, S., \& Maheshwaran, M. (2021). Education sector structural digital transformations in comprehensive Universities of Ethiopia in post COVID-19 periods. Education, 2(6).

- Feyisa, M. B., Feyisa, A. B., Moreda, A. K., \& Hailu, Y. (2022). The practices and challenges of conducting action research in some selected secondary schools of Bale Zone, Oromia, Ethiopia. Educational Action Research, 1-13.

- $\quad$ Getahun, M., \& Mersha, D. (2020). Skill gap perceived between employers and accounting graduates in Ethiopia. Financial Studies, $24(2$ (88)), 65-90.

- $\quad$ Kant S., Muthuraman, M., \& Wata, C. (2021). Links between Entrepreneurship Education Outcomes and Entrepreneurship Behavior in Higher Education: A Review and Evaluation in Case of Ethiopia. Journal of Indigenous Knowledge and Development Studies, 2(2), 94-110.

- $\quad$ Lerra, M. D. (2021). Leadership Competencies for Quality Education in Rural Primary Schools of Ethiopia: The Case of Amhara and Oromia Regional States. Turkish Journal of Computer and Mathematics Education (TURCOMAT), 12(12), 4156-4168.

- MEKONNEN, M. A. (2021). The Causes of youth unemployment among tertiary graduates in Ethiopia (Doctoral dissertation, KDI School).

- Mustapha, A. I., \& Osho, M. O. (2019). The Impact of Manpower Development on Organizational Efficiency in National Inland Waterways Authority of Nigeria (NIWA), International Journal of Arts and Humanities (IJAH) Ethiopia, 8 (1), 103-115.

- $\quad$ Socwell, C. P., Kanagasaba, K., \& Pope, R. (2022). The Utility of Mayo Clinic's Early Screen for Discharge Planning (ESDP) Tool: A Critical Narrative Review. Journal of Acute Care Physical Therapy, 13(1), 24-44.

- Susilaningsih, E., Aprilia, N., \& Hayati, S. (2022). The Effectiveness of Teaching Materials Loaded with Blended Learning with a Scientific Approach on Buffer Solution Learning. Jurnal Inovasi Pendidikan Kimia, 16(1), 59-64.

- Wudneh, L., Seifu, A., \& Dagnew, A. (2022). Practices of cooperative training in the Amhara Regional State TVET colleges and companies, Ethiopia. Cogent Education, 9(1), 2020608.

- $\quad$ Yitbarek, S., Wogasso, Y., Meagher, M., \& Strickland, L. (2022). Life Skills Education in Ethiopia: Afar Pastoralists' Perspectives. In Life Skills Education for Youth (pp. 245-265). Springer, Cham. 